\title{
Larval tolerance to food limitation is stronger in an exotic barnacle than in its native competitor
}

Griffith, Kate; Jenkins, Stuart; Gimenez Noya, Luis

\section{Zoology}

DOI:

10.1016/j.zool.2020.125891

Published: 05/04/2021

Peer reviewed version

Cyswllt i'r cyhoeddiad / Link to publication

Dyfyniad o'r fersiwn a gyhoeddwyd / Citation for published version (APA):

Griffith, K., Jenkins, S., \& Gimenez Noya, L. (2021). Larval tolerance to food limitation is stronger in an exotic barnacle than in its native competitor. Zoology, 145, [125891]. https://doi.org/10.1016/j.zool.2020.125891

\footnotetext{
Hawliau Cyffredinol / General rights

Copyright and moral rights for the publications made accessible in the public portal are retained by the authors and/or other copyright owners and it is a condition of accessing publications that users recognise and abide by the legal requirements associated with these rights.

- Users may download and print one copy of any publication from the public portal for the purpose of private study or research.

- You may not further distribute the material or use it for any profit-making activity or commercial gain

- You may freely distribute the URL identifying the publication in the public portal ?
}

Take down policy

If you believe that this document breaches copyright please contact us providing details, and we will remove access to the work immediately and investigate your claim. 


\section{LARVAL TOLERANCE TO FOOD LIMITATION IS STRONGER IN AN EXOTIC BARNACLE THAN IN ITS NATIVE COMPETITOR \\ --Manuscript Draft--}

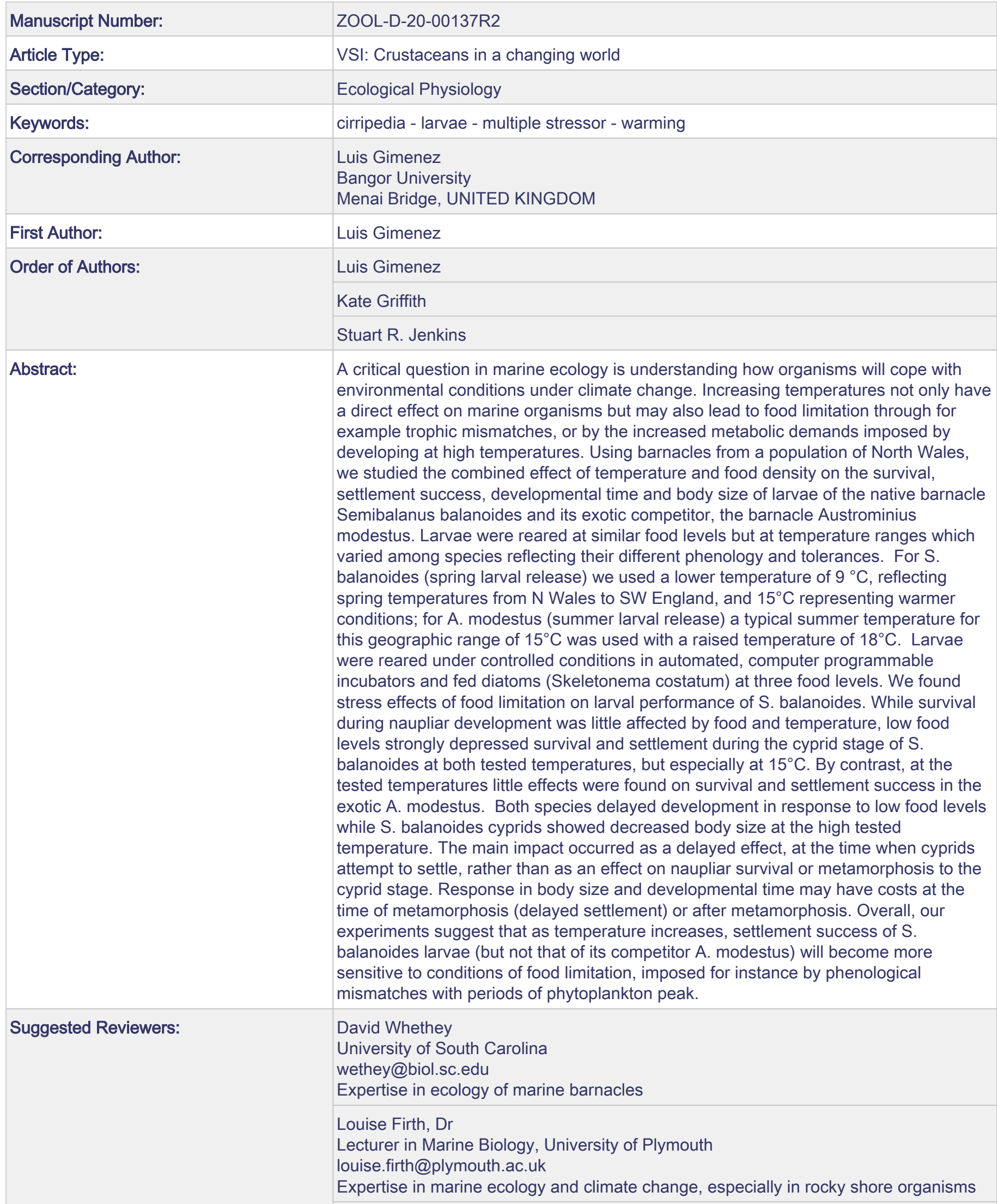


Mark Johnson

Professor, Galway University

mark.johnson@nuigalway.ie

Expertise in population ecology with emphasis on intertidal organisms

Opposed Reviewers:

Response to Reviewers: 
Helgoland 31.11.2020

\section{Dear Editor,}

Please, find the second revised version of the manuscript entitled "Larval tolerance to food limitation is stronger in an exotic barnacle than in its native competitor". We have covered all the minor corrections indicated by the editorial office. We are now submitting the $\mathrm{ms}$ in separated files as requested.

Please, do not hesitate to contact me if you have any question.

Sincerely,

\section{Dr. Luis Giménez}

Biologische Anstalt Helgoland, Alfred Wegener Institute,

Helmholtz Zentrum für Polar and Meeresforschung

27498 Helgoland

Deutschland 
Larval tolerance to food limitation is stronger in an exotic barnacle than in its native competitor. Kate Griffith, Stuart R. Jenkins and Luis Giménez

\section{Highlights}

- Under current warming, cold adapted native barnacle Semibalanus balanoides competes with warm adapted exotic Austrominius modestus

- Food limited larval performance is strong at high temperatures for native S. balanoides

- At similar temperatures and food density, larval performance of the exotic A. modestus is little affected. 
1 2

3

4

5

6

7

8

9

10

11

12

13

14

15

16

17

18

19

20

21

22

23

24

25

\section{LARVAL TOLERANCE TO FOOD LIMITATION IS STRONGER IN AN EXOTIC}

BARNACLE THAN IN ITS NATIVE COMPETITOR

Kate Griffith $^{1}$, Stuart R. Jenkins ${ }^{1}$ and Luis Giménez ${ }^{1,2}$

1. School of Ocean Sciences, Bangor University, Askew Street, LL59 5AB, Anglesey, Wales, United Kingdom.

2. Marine Station of Helgoland, Alfred Wegener Institute, Helmholtz Centre for Polar and Marine Research, Ostkaje 1118, DE-27498 Helgoland, Germany.

10

11

2

3

4

15

6

7

8

9

2

23 


\section{Abstract}

A critical question in marine ecology is understanding how organisms will cope with environmental conditions under climate change. Increasing temperatures not only have a direct effect on marine organisms but may also lead to food limitation through for example trophic mismatches, or by the increased metabolic demands imposed by developing at high temperatures. Using barnacles from a population of North Wales, we studied the combined effect of temperature and food density on the survival, settlement success, developmental time and body size of larvae of the native barnacle Semibalanus balanoides and its exotic competitor, the barnacle Austrominius modestus. Larvae were reared at similar food levels but at temperature ranges which varied among species reflecting their different phenology and tolerances. For S. balanoides (spring larval release) we used a lower temperature of $9{ }^{\circ} \mathrm{C}$, reflecting spring temperatures from $\mathrm{N}$ Wales to SW England, and $15^{\circ} \mathrm{C}$ representing warmer conditions; for A. modestus (summer larval release) a typical summer temperature for this geographic range of $15^{\circ} \mathrm{C}$ was used with a raised temperature of $18^{\circ} \mathrm{C}$. Larvae were reared under controlled conditions in automated, computer programmable incubators and fed diatoms (Skeletonema costatum) at three food levels. We found stress effects of food limitation on larval performance of $S$. balanoides. While survival during naupliar development was little affected by food and temperature, low food levels strongly depressed survival and settlement during the cyprid stage of $S$. balanoides at both tested temperatures, but especially at $15^{\circ} \mathrm{C}$. By contrast, at the tested temperatures little effects were found on survival and settlement success in the exotic A. modestus. Both species delayed development in response to low food levels while S. balanoides cyprids showed decreased body size at the high tested temperature. The main impact occurred as a delayed effect, at the time when cyprids attempt to settle, rather than as an effect on naupliar survival or metamorphosis to the cyprid stage. Response in body size and developmental time may have costs at the time of metamorphosis (delayed settlement) or after metamorphosis. Overall, our experiments suggest that as temperature increases, settlement success of $S$. balanoides larvae (but not that of its competitor A. modestus) will become more sensitive to conditions of food limitation, imposed for instance by phenological mismatches with periods of phytoplankton peak.

Keywords: cirripedia - larvae - multiple stressor - warming 
 \\ 1. Introduction}

A key current question in ecology concerns the action of multiple climate driven variables on organisms, populations and communities. Climate change involves a modification of a large number of environmental variables which can act simultaneously, potentially altering performance and fitness (Crain et al., 2008; Hoffmann and Sgro, 2011; Piggott et al., 2015). In addition, climate driven environmental variables can provide a novel context for how natural variation in limiting factors are handled by organisms (Spitzner et al., 2019). For example, in the marine habitat, larval stages of crustaceans and fish are thought to experience a food limited environment (Barnes, 1956; Olson and Olson, 1989; Gotceitas et al., 1996; Gimenez and Anger, 2005; Le Pape and Bonhommeau, 2015). In seasonal habitats, increases in temperature can be accompanied by reductions in food availability because of phenological mismatches, between periods of larval development and that of food production (Edwards and Richardson, 2004). In addition, and irrespective of changes in food availability, increased temperature results in increased metabolic demands and "cost of living"' (Somero, 2002). Those costs are likely to exacerbate effects of food limitation on survival, development and growth (Giebelhausen and Lampert 2001; GonzálezOrtegón and Giménez 2014; Torres and Giménez 2020).

Another concern is that climate change has been accompanied by range expansion or introduction of exotic, potentially warm tolerant, species (e.g. Hickling, et al., 2006; Burrows et al., 2011; Poloczanska et al., 2013), which can produce important modifications in natural communities if they become invasive (Simberloff, 2009; Gurevitch et al., 2011). In regions where warming is accompanied by the arrival of exotic species, the overall result is that native species are faced with harsher habitats but also need to invest extra resources in competing with exotic species. An important point is however that the exotic species may have to cope with similar levels of food limitation and increased temperature as the natives. Hence, the overall effect of increased temperature, nutritional limitation and competition will depend on how both native and exotic competitor fare in the light of warming.

Here, we study a system of competing barnacles composed of a native species (Semibalanus balanoides) that is facing warming and the presence of an exotic competitor (Austrominius modestus), introduced from New Zealand (Crisp, 1958; Harms, 1987). Both species co-occur as 
juvenile-adults in rocky intertidal zones of North Europe (Crisp and Davies, 1955; Harms, 1982; Torres et al., 2016) while larvae develop and grow in open coastal waters. The barnacle $S$. balanoides releases a single brood of pelagic larvae during the spring (Barnes, 1956, 1957a, 1962); A. modestus, however, releases larvae over spring and summer (Crisp and Davies, 1955). Our study focuses on the larval phase because available information on success and failure of recruitment suggest that, at least in $S$. balanoides, larvae are quite sensitive to natural variations in food availability (Barnes, 1956; Hawkins and Hartnoll, 1982; Cole et al., 2011) and because changes in larval physiological quality can drive settlement success and post-metamorphic survival (Jarret, 2003). Combined negative effects of high temperature and food limitation may occur for instance after warm winters, which are known to impact recruitment in S. balanoides (Polaczanska et al., 2008; Abernot-Le Gac et al., 2018). More generally, larvae tend to be highly sensitive to environmental fluctuations (Pandori and Sorte, 2019) and make a strong contribution to the recovery and persistence of marine populations following disturbance (Cowen and Spounagle, 2009; Pineda et al., 2009; Gimenez et al., 2020). We therefore quantify the effect of food level and temperature on survival of larvae, cyprid size, rate of development and the subsequent metamorphic success. While larval survival and metamorphic success provide an indicator of effects that are relevant in the context of larval settlement rates, changes in development time and body size, point towards potential trait-mediated effects (Torres et al., 2016; Gimenez et al., 2017) whereby changes in physiological traits driven by larval experience affect post-metamorphic survival. We predict that $S$. balanoides, with larval release synchronised to phytoplankton blooms (Barnes, 1956, 1962; Hawkins and Hartnoll, 1982; Starr et al., 1991), should show lower tolerance to low food levels than A. modestus, which does not synchronise its larval release to an environmental cue. We also predict that the ability of both species to tolerate low food conditions will be impaired at species-specific high temperature levels.

\section{Materials and Methods}

\subsection{Experimental design}

Larvae hatched from broods produced by different parents were exposed to combinations of two temperatures and three food levels in a factorial design (Fig. 1). Because the model species differ in their temperature optima (Harms, 1987), we evaluated the role of food limitation at speciesspecific temperatures (S. balanoides: $9{ }^{\circ} \mathrm{C}$ and $15{ }^{\circ} \mathrm{C}$; A. modestus: $15^{\circ} \mathrm{C}$ and $18{ }^{\circ} \mathrm{C}$ ) ensuring 
mortality rates $<25 \%$ at optimal food conditions (Harms, 1987), but enabling direct comparison of responses at one of the temperature treatments. Our choice of temperature is based on those experienced by larvae released from barnacles over the geographic extent of SW Great Britain, N. France and Spain, during the period of larval release and development (spring for S. balanoides, summer for A. modestus). Thus $9{ }^{\circ} \mathrm{C}$ represents spring time temperatures under which $S$. balanoides typically develops, with $15{ }^{\circ} \mathrm{C}$ used to represent particularly warm conditions. For $A$. modestus which breeds throughout the year but with predominant larval development in summer months, 15 and $18{ }^{\circ} \mathrm{C}$ were used to represent normal and elevated conditions respectively.

Larvae were fed the diatom Skeletonema costatum which is known to promote development in both species (Moyse, 1963; Tighe-Ford, 1970; Barker, 1976; Harms, 1987; Stone, 1989). There were three food levels: high food (HF): 4 x 10 $0^{5}$; mid food (MF): 2 x $10^{5}$ and low food (LF): 4 x $10^{4}$ cells ml ${ }^{-1}$. The two highest food levels were within the range used by Harms (1987) and Stone (1989). A preliminary experiment (Supplementary data: Fig. S1) showed us that the choice of food treatments and a temperature of $15^{\circ} \mathrm{C}$ to perform direct comparisons among species, leds to successful survival and settlement for both species. For each experiment, four adults with ripe embryos were selected; larvae from each adult were reared under the 2 different temperatures for each of the 3 experimental food levels. In summary, for the main experiment we used a total of 120 replicate units (= 5 units $\times 3$ food levels $\times 2$ temperature levels $\times 4$ adults) and 1200 larvae (= 10 larvae x 120 replicate units) per barnacle species. For the preliminary experiment we also used 10 larvae per replicate unit and a total of 120 replicate units and 1200 larvae per species, but organised in 5 units $x 3$ food levels $x 2$ shores $x 4$ barnacles per shore.

\subsection{Collection of animals and culturing procedures}

Experiments were carried out in February 2012 for S. balanoides and in October 2012 for A. modestus (preliminary experiment in April-July 2010). For each experiment, adults were collected from a location on the Menai Strait $\left(53^{\circ} 13^{\prime} 16 \mathrm{~N}, 04^{\circ} 09^{\prime} 47 \mathrm{~W}\right)$ and left to hatch. Adult barnacles

of $S$. balanoides and A. modestus were collected by scraping intact individuals from the substratum. Upon return to the laboratory, adults that contained broods of ripe embryos were identified and placed individually in separate $100 \mathrm{ml}$ plastic containers containing $0.45 \mu \mathrm{m}$ filtered seawater (FSW). These were left for up to 2 hours to allow hatching of stage I nauplii (Crisp, 1956). Only adults where most of the larval brood had readily hatched were deemed appropriate 
146 for experimental use and, from these, four adults were randomly selected for the experiment. 147 Larvae were transferred to experimental culture vessels (10 larvae per 100ml vessel). All 148 replicates were reared in automated incubators with a 12:12h light: dark photoperiod at the 149 designated experimental temperature.

150 Diatoms Skeletonema costatum (strain: CCAP 1077/5) were provided at appropriate cell densities 151 every 2 days with provision of algae coinciding with the time of water change. Prior to each

152 153 154 155 156 157 158 159 160 161 162 163 feeding, $S$. costatum were collected from cultures (grown in Conway medium with added silicates and FSW; Laing, 1991) and culture cell density was determined with a haemocytometer. Algal cultures were reared in 4 or 10 litre Pyrex borosilicate flasks at $18-19^{\circ} \mathrm{C}$ with a $24 \mathrm{hr}$ light cycle. Larval culture water was changed by pouring the contents of a replicate jar into a small glass bowl and, using a Pasteur pipette, larvae were moved to a watch glass for microscopic examination. After examination, larvae were returned to a clean jar already containing S. costatum and FSW at the appropriate experimental temperature and food density. During microscopic examination, larvae were checked for mortality and for average larval development stage (naupliar stages I-VI: Crisp, 1962; Knight Jones and Waugh, 1949). Larvae within each replicate were observed every 2 days until the first appearance of cyprids, after which time, larval cultures were checked daily (with water change and feeding still taking place every 2 days). All cultures ran until larvae had either died or moulted to the final larval cyprid stage. When the cyprid stage was reached, cyprids were removed from cultures and subsequently used to determine settlement rates.

When larvae had developed to the cyprid stage, the cyprids from each adult reared under each food treatment and temperature condition were pooled together in 1 jar. Cyprids were kept in the incubator in FSW at the same temperature they were reared under. Ten cyprids from each adult at each treatment were selected at random and photographed using a microscope camera GX-CAM 5. Photographs were subsequently analysed using Image $\mathrm{J}$ to calculate the length, width and cyprid area. Cyprids were then returned to the cultures for settlement rates analysis. For this, a settlement surface was introduced to the vessel containing the cyprids and the resulting settlement rates were observed. Clean rock scraped from conspecific barnacles were provided as a settlement surface. On day 2, 4, 6 and 8 (after the rock had been added) the cyprid cultures were examined and the water was changed. During examination, numbers of metamorphosed cyprids upon the rocks were counted and any dead cyprids in the jar were removed. 
178 The instantaneous mortality rates (M) of larvae during naupliar development (hatching to cyprid) 179 and cyprid settlement were calculated as $\mathrm{M}=\ln \left(\mathrm{N}_{0} / \mathrm{N}_{\mathrm{t}}\right) / \mathrm{t}$, where $\mathrm{t}=$ specific time interval; $\mathrm{N}_{\mathrm{t}}=$ number of larvae after a specific time interval $(\mathrm{t})$; and $\mathrm{N}_{\mathrm{o}}=$ initial number of larvae. Using this method, the average $\mathrm{M}$ for each food and temperature treatment were calculated for both the period of hatching to cyprid and the subsequent cyprid to settlement period for each species.

Statistical analyses were run in R (R Core Team 2013), using model selection based on the adjusted Akaike information criteria (AICc), using backward removal, following Zuur et al. (2009) and Galecki and Burzykowski (2013). The response variables were duration of development from hatching to the cyprid stage per replicate, percentage survival to cyprid per replicate, percentage settlement and mean cyprid size; all these variables were analysed through mixed modelling, using the package nlme (Pinheiro et al., 2018). Student Newman Keul's (SNK) was used for post-hoc multiple comparisons.

For survival and developmental time to cyprids, we fitted models containing random terms (based on parent of origin) as well as fixed terms (i.e. effects of temperature and food on average trends), using the lme function. Model selection for the random terms were carried out through restricted maximum likelihood (REML). Once the best random structure was fitted, we used maximum likelihood (ML) for model selection on the fixed structure. For settlement success we had a single replicate per parent; therefore, we fitted models, using the $g l s$ function, based on a within subjectdesign (where parents were the subjects), by adding a correlation term (corCompSymm constructor 197 function).

198 Estimates of variance components were used to evaluate patterns of variability in the response 199 variables among random factors (shore, parent and replicate) for each experimental treatment. The 200 relative variance components were estimated for each source of variation by using the observed 201 mean squares to estimate terms identified in the expected mean squares (Searle et al. 1992; 202 Underwood, 1997; Graham and Edwards, 2001). Sometimes one or more estimates from the 203 ANOVA method were negative; then, these estimates were set to zero, removed from the model 204 and the estimates for the remaining factor re-calculated according to Fletcher and Underwood 
205 (2002). Untransformed data were used throughout to provide variance components comparable 206 across all data (Fraschetti et al. 2005).

207 3. Results

208

209

210

211

212

213

214

215

216

217

218

219

220

221

222

223

224

225

226

227

228

229

230

231

232

233

\subsection{Naupliar survival and settlement rates}

For both $S$. balanoides and A. modestus, survival to cyprid was high (>80\%) under all of the experimental treatments (Fig. 2a, b); hence, effects of food limitation or temperature on survival were weak. For $S$. balanoides, the best models did not include food or temperature as main factors driving survival to the cyprid stage (Table 1). The effect of food and temperature on survival rates of $S$. balanoides varied among individuals hatching from different parents (best model included parent of origin in their random part: supplementary material: Table S1). Most important variation among parents of $S$. balanoides occurred at the high temperature, especially at low food levels (supplementary material: Fig. S2). For A. modestus, the best models retained food and temperature but the actual effect was weak, as survival was very high, $>90 \%$, under all experimental conditions (Fig. 2b). Post-hoc tests on averages by parent did not detect differences among treatments and variance components indicated low contribution of parents to the total variability for this species (supplementary material: Fig. S2).

Settlement rates were more responsive to food condition in S. balanoides than in A. modestus (Fig. 3a, b). In S. balanoides, both temperature and food condition were retained in the best statistical models (Tables 1 and S2 for details) but the effect of temperature was weak. Settlement was reduced under low food levels (Fig. 3a) especially at the high temperature treatment $\left(15^{\circ} \mathrm{C}\right)$, with only $48 \%$ of the larvae settling compared to $77 \%$ at $15^{\circ} \mathrm{C}$ for the mid and high food (no significant differences between high and mid food). In A. modestus, neither food nor temperature were retained in the best models for settlement rate; settlement rates were high $(>70 \%)$ under all experimental treatments (Fig. 3a).

In S. balanoides, failure in settlement occurred mainly through reduced cyprid survival (compare figure $2 \mathrm{a}$ vs $3 \mathrm{a}$ ). This is shown by the fact that cyprid survival (i.e. the proportion of settlers calculated over the number of cyprids: Fig. 3c) explains most of the overall larval survival (calculated on the basis of the number of larvae hatched: Fig. 3a). For cyprid survival, both food and temperature were included in the best model (Table 1) in a manner consistent with an 
234 independent contribution of temperature and food on survival. In A. modestus the proportion of 235 cyprid larvae settling was high irrespective of temperature (Fig. 3d).

236 Mortality was higher during the cyprid settlement stage in comparison to the naupliar stages (Table 237 2). During the cyprid settlement phase for S. balanoides, estimated mortality rates were at their 238 highest in the low food treatments (at $9{ }^{\circ} \mathrm{C} \mathrm{M}=0.085 \mathrm{~d}^{-1}$; at $15^{\circ} \mathrm{C} \mathrm{M}=0.157 \mathrm{~d}^{-1}$ ) when compared to the high and mid food treatments where $\mathrm{M}<0.058 \mathrm{~d}^{-1}$ (Table 2). In contrast, for A. modestus settlement mortality remained low (range 0.017-0.045) and did not vary substantially among food and temperature treatments.

\subsection{Developmental time and cyprid size}

243

244

245

246

247

248

249

250

251

252

253

254

255

256

257

258

259

260

261

262

263

For both species, the best models included interactive effects of temperature and food on developmental time from hatching to cyprid (Tables 1 and S1). Both species had a shorter developmental time when the larvae experienced the high/mid food rations and/or the higher temperature condition (Fig. 4a, b). In S. balanoides, exposure to $15^{\circ} \mathrm{C}$ had a disproportionate impact upon duration of larval development under food limited conditions; at $9{ }^{\circ} \mathrm{C}$, development took $18 \%$ longer at the low food conditions compared to rates observed at high and mid food levels, but food limitation resulted in an increase of $32 \%$ in duration of development at $15^{\circ} \mathrm{C}$ (Fig. 4a). In A. modestus, the effects were proportionally smaller (16-18\% longer under low vs highmid food levels). In both species the effect of temperature and food on duration of development varied among larvae from different parents (variation among parents was retained in the random structure of the best models: Table S1), but for all parents, larvae took a longer time to develop at the low food level and lower temperature (Fig. 4c, d). Variance components identified that variation in developmental time occurred mainly among parents for most of the experimental treatments, apart from $S$. balanoides at mid food $/ 15^{\circ} \mathrm{C}$ and high food $/ 15^{\circ} \mathrm{C}$ where the greatest variation was among replicates.

For both species, the best models included interactive effects of food and temperature on cyprid size (Tables 1 and S1). The smallest cyprids were produced at the highest temperature and lowest food (Fig. 5). For S. balanoides, increased temperatures led to size reductions of 11-20\% depending on food condition, while the low food treatment resulted in a size reduction of $18 \%$ at $9{ }^{\circ} \mathrm{C}$ and $24 \%$ at $15^{\circ} \mathrm{C}$ as compared to those reared at high and mid food. For A. modestus cyprids, the effect of temperature was small (size reduction in the range 4\%-10\%); however, cyprids at the 
low food treatment were $18 \%$ smaller at $15{ }^{\circ} \mathrm{C}$ and $21 \%$ smaller at $18{ }^{\circ} \mathrm{C}$ than at high and mid food for the same temperature. Parental variation was more important for S. balanoides than for $A$. modestus (Fig. 5c, d, Fig. S2).

\section{Discussion}

We found that responses of larvae to experimental conditions were consistent with the original hypotheses that a decrease in food abundance would have important consequences for the settlement success of $S$. balanoides but not for A. modestus. Larval food limitation did not affect the success of naupliar development into the cyprid stage, but led to a failure in cyprid settlement in $S$. balanoides. Under the mid and high food levels, survival compared well with data from previous studies for larvae reared under ad libitum food (e.g. Tighe-Ford, 1970; Harms, 1984: percentage survival of $>80 \%$ for $S$. balanoides was in the range of $6-18{ }^{\circ} \mathrm{C}$ and $>70 \%$ for $A$. modestus in the range $12-20{ }^{\circ} \mathrm{C}$ ).

Our findings, integrated with information on fertilization, embryogenesis and recruitment, contribute to achieve a better understanding of how increased temperatures can drive population persistence of S. balanoides over the southern part of its distribution range. Because of the temperatures used, the ecological relevance of our analysis is restricted to the southern distribution limit of S. balanoides in Europe (SW Great Britain, N. France, Spain), but not the northern distribution range (including e.g. Spitzbergen: Barnes, 1957b), nor the Atlantic coast of N. America where larvae experience much lower temperatures than those tested here (Pineda et al., 2005). The same holds for A. modestus that in Europe reaches the western Mediterranean (Galil, 2009) where larvae are likely to experience temperatures $>18^{\circ} \mathrm{C}$. Previous studies have indicated that temperature effects on fertilization and embryogenesis of $S$. balanoides can cause changes in distribution range and failures in recruitment (Rognstad et al., 2014; Crickenberger and Wethey, 2018). Overall, evidence suggests that the mechanism driving failure in recruitment appears to vary along the southern range of the distribution, with reproductive failures occurring in Spain and France, and mismatches between larvae and phytoplankton occurring further north, in S. England (Crickenberger and Wethey, 2018). We found that at temperatures similar to those of the southern limit of distribution of $S$. balanoides, or in a scenario of warming, food limitation reduces settlement success through delayed effects on the proportion of cyprids successfully settling rather 
than an effect on nauplius survival. Such a delayed effect appears to be similar to that reported in other barnacles (Thiyagarajan et al., 2002; Tremblay et al., 2008). In S. balanoides, low settlement success may reflect reduced levels of nutritional reserves (Jarret et al., 2003) rather than costs associated with settling with a smaller body size. A large amount of such reserves are consumed in the processes of settlement and metamorphosis (Lucas et al., 1979). By contrast, for the tested temperatures, no such reduction in settlement success was detected in A. modestus. We do not know how A. modestus larvae would respond to food limitation if larvae were to experience temperatures $>18{ }^{\circ} \mathrm{C}$; the highest recorded survival rates are achieved at $24-25{ }^{\circ} \mathrm{C}$ (Barker 1972 , Harms, 1987) but no information is available on larvae performance under food limitation above $18^{\circ} \mathrm{C}$.

When responses in cyprid body size are integrated with those of naupliar developmental time (summarised in Fig. 6) we see important pointers towards potential fitness costs of developing under combinations of high temperature and food limitation. Those costs would be manifested as effects of larval experience on body size of juveniles and on the timing of metamorphosis, which subsequently may drive post-settlement or post-metamorphic survival (Thiyagarajan et al., 2005; Emlet and Sadro, 2006; Torres et al., 2016). We interpret those changes as driven by phenotypic plasticity because naupliar survival was high across treatments. In cases where phenotypic responses occur with a concomitant mortality, the observed phenotypic changes may occur due to phenotypic selection (Hechtel and Juliano, 1997). For instance, if food limitation impacts negatively only those individuals characterized by high growth rate, then the survivors would be over-represented by individuals characterized by low growth rates; hence, the average body size would be biased towards lower values. In our case however, phenotypic selection should play a minor role in driving trait responses; in addition, responses were consistent among larvae obtained from different parents. Low food levels led to correlated responses of increasing developmental time and reducing body size, consistent with general predictions of models of metamorphosis (Hentschel, 1999; Hentschel and Emlet, 2000; West and Costlow, 1987). In S. balanoides, maximum body size was contingent on temperature, consistent with the temperature-size rule (Atkinson, 1994; Zuo et al., 2012). A. modestus was able to maintain similar body sizes across the range of temperatures experienced $\left(15-18{ }^{\circ} \mathrm{C}\right)$ despite changes in the developmental time; reductions in body size may however occur above $18{ }^{\circ} \mathrm{C}$ as suggested by the reduction of energy content in larvae reared at $24{ }^{\circ} \mathrm{C}$ (Harms, 1987). In the field, one would expect consequences 

associated with arriving late, such as limited access to available substratum, and costs associated with reduced body size such as reduced growth and survival (Jarret et al., 2003; Torres et al., 2016).

An important result was that responses were consistent across larvae obtained from different parents. We observed some variation among parents in the responses for $S$. balanoides which may be related to embryonic experience (Lucas and Crisp, 1987), but larval performance was consistently reduced under food limitation. Hence, in both species, but particularly in A. modestus, there were little effects of the parental environment or genetic variation on larval performance. The response of $S$. balanoides larvae to high temperature and low food levels was found both in our preliminary and definitive experiments (Figs. S1 and 3), based on larvae obtained from parents collected from two different intertidal shores and in different years. Hence, our experiments do not provide evidence for strong variation for tolerance to food limitation at $15{ }^{\circ} \mathrm{C}$, at least at the scale of our local population. Some variation for tolerance to food limitation and increased temperature, in particular in S. balanoides, would have pointed to potential room for an evolutionary response to climate change (Appelbaum et al., 2014). In other cases, important intraspecific variation is found within a local population (Carter et al., 2013; Spitzner et al., 2019). Perhaps populations located towards the southern limit of distribution show increased tolerance to food limitation under increased temperature.

\section{Conclusions}

Overall, our study highlights the stress effects of increased temperature and food limitation on larval performance of $S$. balanoides, which may translate to settlement failure in the field. Stress responses are manifested as a delayed effect, at the time when cyprids attempt to settle, rather than as an effect on naupliar survival or metamorphosis to the cyprid stage. Given that the effect of food limitation on larval performance can increase with temperature (Torres and Giménez, 2020), it remains to be determined if the sensitivity of $S$. balanoides larvae to low food levels decreases towards lower temperatures $\left(3-6{ }^{\circ} \mathrm{C}\right)$ experienced in the northern sector of the distribution range. In larvae of $A$. modestus, such effects do not occur although larvae of the local population are expected to develop at $14-16^{\circ} \mathrm{C}$.

Conflict of interest: All authors declare no conflict of interest 


\section{References}

356 Abernot-Le Gac C., Antajan E., Courtay G., Drévès L., Hernandez Farinas T., Lamort L., Loots

357 C., Rabiller E, Ropert M., Schlaich I., 2017. Surveillance écologique et halieutique du site de 358 Flamanville, année 2017. Ifremer RST. ODE/LITTORAL/LER / BO / 18.01 - Avril 2018, 231 p. 359 Available at: https://archimer.ifremer.fr/doc/00458/57008/58904.pdf. Last accessed: 22.10.2020.

360 Appelbaum, S.L., Pan, T.C.F., Hedgecock, D., Manahan, D.T., 2014. Separating the nature and 361 nurture of the allocation of energy in response to global change. Integr. Comp. Biol. 54, 284-295. 362 Atkinson, D., 1994. Temperature and organism size - a biological law for ectotherms? Adv. Ecol. 363 Res. 25, 1-58.

364 Barker, M. F. 1976 Culture and morphology of some New Zealand barnacles (Crustacea: 365 Cirripedia), New Zealand Journal of Marine and Freshwater Research, 10:1, 139-158,

366 Barnes, H., 1956. Balanus balanoides (L.) in the Firth of Clyde: the development and annual 367 variation of the larval population, and the causative factors. J. Anim. Ecol. 25, 72-84.

368 Barnes, H., 1957a. Processes of restoration and synchronization in marine ecology. The spring 369 diatom increase and the "spawning" of the common barnacle Balanus balanoides (L.). Année 370 Biol. 33, 67-85.

371 Barnes, H., 1957b. The northern limits of Balanus balanoides. Oikos 8, 1-15.

372 Barnes, H., 1962. So-called anecdysis in Balanus balanoides and the effect of breeding upon the 373 growth of the calcareous shell of some common barnacles. Limnol. Oceanogr. 7, 462-473.

374 Burrows M.T., Schoeman, D.S., Buckley, L., Moore, P., Poloczanska, E.S., 2011. The pace of 375 shifting climate in marine and terrestrial ecosystems. Science 334, 652-655.

376 Carter, H.A., Ceballos-Osuna, L., Miller, N.A., Stillman, J.H., 2013. Impact of ocean acidification 377 on metabolism and energetics during early life stages of the intertidal porcelain crab Petrolisthes 378 cinctipes. J. Exp. Biol 216, 1412-1422.

379 Cole, S.W.B., Scrosati, R.A., Tam, J.C., Sussmann, A.V., 2011. Regional decoupling between NW 380 Atlantic barnacle recruit and adult density is related to changes in pelagic food supply and benthic 381 disturbance. J. Sea Res. 65, 33-37. 
382 Cowen, R.K., Sponaugle, S. 2009. Larval dispersal and marine population connectivity. Annu. 383 Rev. Mar. Sci. 1, 443-466.

384 Crain, C.M., Kroeker, K., Halpern, B.S., 2008. Interactive and cumulative effects of multiple 385 human stressors in marine systems. Ecol. Lett. 11, 1304-1315.

386 Crickenberger, S., Wethey, D.S., 2018. Reproductive physiology, temperature and biogeography: 387 the role of fertilization in determining the distribution of the barnacle Semibalanus balanoides. J. 388 Mar. Biol. Ass. U. K. 98, 1411-1424.

389 Crisp, D. J., 1956. A substance promoting hatching and liberation of young in cirripedes. Nature 390178,263

391 Crisp, D. J., 1958. The spread of Elminius modestus Darwin in north- west Europe. J. Mar. Biol. 392 Assoc. UK, 37, 483- 520

393 Crisp, D. J., 1962. The planktonic stages of the Cirripedia Balanus balanoides (L.) and B 394 alanus balanus (L.) from north temperate waters. Crustaceana, 207- 221.

395 Crisp, D. J., Davies, P. A., 1955. Observations in vivo on the breeding of Elminius modestus grown 396 on glass slides. J. mar. biol. Ass. UK. 34, 357-380.

397 Edwards, M., Richardson, A.J., 2004. Impact of climate change on marine pelagic phenology and 398 trophic mismatch. Nature 430, 881-884.

399 Emlet, R.B., Sadro, S.S., 2006. Linking stages of life history: How larval quality translates into 400 juvenile performance for an intertidal barnacle (Balanus glandula). Integr. Comp. Biol. 46, 334401346.

402 Fletcher, D. J., Underwood, A. J., 2002. How to cope with negative estimates of components of 403 variance in ecological field studies. J. Exp. Mar. Biol. Ecol. 273, 89-95.

404 Fraschetti, S., Terlizzi, A., Benedetti-Cecchi, L., 2005. Patterns of distribution of marine 405 assemblages from rocky shores: evidence of relevant scales of variation. Mar. Ecol. Progr. 406 Ser. 296, 13-29.

407 Galecki, A., Burzykowski, T., 2013. Linear Mixed-Effect Models Using R. Springer, New York 408241. 
Galil, B.S., 2009. Taking stock: inventory of alien species in the Mediterranean Sea. Biol. Invasions 11, 359-372.

Giebelhausen, B., Lampert, W., 2001. Temperature reaction norms of Daphnia magna: the effect of food concentration. Freshwater Biol. 46, 281-289.

Giménez, L., Anger, K., 2005. Effects of temporary food limitation on survival and development of brachyuran crab larvae. J. Plankton Res. 27, 485-494.

Giménez, L., Torres, G., Pettersen, A., Burrows, M.T., Estevez, A., Jenkins, S.R., 2017. Scaledependent natural variation in larval nutritional reserves in a marine invertebrate: implications for recruitment and cross-ecosystem coupling. Mar. Ecol. Progr. Ser. 570, 141-155.

Giménez, L., Robins, P., Jenkins, S.R., 2020. Role of trait combinations, habitat matrix, and network topology in metapopulation recovery from regional extinction. Limnol. Oceanogr. 65, $775-789$.

González-Ortegón, E., Giménez, L., 2014. Environmentally mediated phenotypic links and performance in larvae of a marine invertebrate. Mar. Ecol. Progr. Ser. 502, 185-195.

Gotceitas, V., Puvanendran, V., Leader, L.L., Brown, J.A., 1996. An experimental investigation of the 'match/mismatch' hypothesis using larval Atlantic cod. Environ. Biol. Fish. 130, 29-37.

Graham, M. H., Edwards, M. S., 2001. Statistical significance versus fit: estimating the importance of individual factors in ecological analysis of variance. Oikos 93, 505-513.

Gurevitch, J., Fox, G.A., Wardle, G.M., Inderjit, Taub, D., 2011. Emergent insights from the synthesis of conceptual frameworks for biological invasions. Ecol. Lett. 14, 407-418.

Harms, J., 1986. Effects of temperature and salinity on larval development of Elminius modestus (Crustacea, Cirripedia) from Helgoland (North Sea) and New Zealand. Helgoländer Meeresunters. 40, 355-376.

Harms, J., 1987. Energy budget for the larval development of Elminius modestus (Crustacea: Cirripedia). Helgoländer Meeresunters. 41, 45-67.

Harms, J., 1984. Influence of water temperature on larval development of Elminius modestus and Semibalanus balanoides (Crustacea, Cirripedia). Helgolander Meeresunters. 38, 123-134. 
Hawkins, S. J., Hartnoll, R. G., 1982. Settlement patterns of Semibalanus balanoides (L.) in the Isle of Man (1977-1981). J. Exp. Mar. Biol. Ecol. 62, 271-283.

Hentschel, B.T., 1999. Complex life cycles in a variable environment: Predicting when the timing of metamorphosis shifts from resource dependent to developmentally fixed. Am. Nat. 154, 549558.

Hentschel B.T, Emlet R.B., 2000. Metamorphosis of barnacle nauplii: effects of food variability and a comparison with amphibian models. Ecology 81, 3495-3508.

Hechtel, L.J., Juliano, S.A., 1997. Effects of predator on prey metamorphosis: plastic responses by prey or selective mortality? Ecology $78,838-851$.

Hickling R., D. B. Roy, J. K. Hill, R. Fox \& Thomas, C. D., 2006. The distributions of a wide range of taxonomic groups are expanding polewards. Global Change Biol. 12, 450-455.

Hoffmann, A.A., Sgro, C.M., 2011. Climate change and evolutionary adaptation. Nature 470, 479485.

Hughes, L., 2000. Biological consequences of global warming: is the signal already apparent? Trends Ecol. Evol. 15, 56-61.

IPCC, 2007. Climate Change 2007-The Physical Science Basis: Working Group I Contribution to the Fourth Assessment Report of the IPCC (Vol. 4). Cambridge University Press.

Jarrett, J.N., 2003. Seasonal variation in larval condition and post-settlement performance of the barnacle Semibalanus balanoides. Ecology, 84, 384-390.

Jarrett, J. N., Pechenik, J. A., 1997. Temporal variation in cyprid quality and juvenile growth capacity for an intertidal barnacle. Ecology 78, 1262-1265.

Knight-Jones, E. W., Waugh, G., 1949. On the larval development of Elminius modestus Darwin. J. Mar. Biol Assoc. UK 28, 413-428.

Laing, I., 1991. Cultivation of marine unicellular algae. MAFF Laboratory Leaflet Number 67:31 Le Pape, O., Bonhommeau, S., 2015. The food limitation hypothesis for juvenile marine fish. Fish and Fisheries 16, 373-398. 
Lucas, M.I., Crisp, D.J. 1987. Energy metabolism of eggs during embryogenesis in Balanus balanoides. J. Mar. Biol. Ass. U.K. 67, 27-54.

Lucas, M.I., Walker, G., Holland, D.L., Crisp, D.J., 1979. An energy budget for the free-swimming and metamorphosing larvae of Balanus balanoides (Crustacea: Cirripedia). Mar. Biol. 55, 221229.

Moyse, J., 1963. A comparison of the value of various flagellates and diatoms as Food for Barnacle Larvae. ICES J. Mar. Sci. 28, 175-187.

Olson, R. R., Olson, M. H., 1989. Food limitation of planktotrophic marine invertebrate larvae: does it control recruitment success? Ann. Rev. Ecol. Syst. 20, 225-247.

Pandori, L.L.M., Sorte, C.J.B., 2019. The weakest link: sensitivity to climate extremes across life stages of marine invertebrates. Oikos 128, 621-629.

Piggott, J.J., Townsend, C.R., Matthaei, C.D., 2015. Climate warming and agricultural stressors interact to determine stream macroinvertebrate community dynamics. Global Change Biol. 21, 1887-1906.

Pineda, J., DiBacco, C. \& Starczak, V., 2005. Barnacle larvae in ice: survival, reproduction, and time to postsettlement metamorphosis. Limnol. Oceanogr. 50, 1520-1528.

Pineda, J., Reyns, N.B. \& Starczak, V.R., 2009. Complexity and simplification in understanding recruitment in benthic populations. Pop. Ecol. 51, 17-32.

Pinheiro, J., Bates, D., DebRoy, S., Sarkar, D. and R Core Team, 2018. nlme: Linear and Nonlinear Mixed Effects Models. R package version 3.1-137.

Poloczanska, E. S., Hawkins, S. J., Southward, A. J., Burrows, M. T., 2008. Modelling the response of populations of competing species to climate change. Ecology 89, 3138-3149.

R Core Team, 2013. R: A language and environment for statistical computing. R Foundation for Statistical Computing, Vienna, Austria. URL http://www.R-project.org/.

Rognstad, R.L., Wethey, D.S., Hilbish, T.J., 2014. Connectivity and population repatriation: limitations of climate and input into the larval pool. Mar. Ecol. Progr. Ser. 495, 175-183.

Searle, S. R., Casella G, McCulloch C, 1992. Variance Components. Wiley, New Jersey. 
Simberloff, D., 2009. The role of propagule pressure in biological invasions. Annu. Rev. Ecol. Evol. Syst. 40, 81-102.

Somero, G. N., 2002. Thermal physiology and vertical zonation of intertidal animals: optima, limits, and costs of living. Integr. Comp. Biol. 42, 780-789.

Spitzner, F., Giménez, L., Meth, R., Harzsch, S., Torres, G., 2019. Unmasking intraspecific variation in offspring responses to multiple environmental drivers. Mar Biol. 166: 112.

Starr, M., Himmelman, J. H., Therriault, J.C., 1991. Coupling of nauplii release in barnacles with phytoplankton blooms: a parallel strategy to that of spawning in urchins and mussels. J. Plankton Res13, 561- 571.

Stone, C. J., 1989. A comparison of algal diets for cirripede nauplii. J. Exp. Mar. Biol. Ecol. 132, $17-40$.

Thiyagarajan, V., T. Harder, Qian, P. Y., 2002. Relationship between cyprid energy reserves and metamorphosis in the barnacle Balanus amphitrite Darwin (Cirripedia; Thoracica). J. Exp. Mar. Biol. Ecol. 280, 79-93.

Thiyagarajan V, Hung O. S., Chiu J. M. Y., Wu R. S. S., Qian P. Y., 2005. Growth and survival of juvenile barnacle Balanus amphitrite: interactive effects of cyprid energy reserve and habitat. Mar. Ecol. Prog. Ser 299, 229-237.

Tighe-Ford, D.J., Power, M.J.D., Vaile, D.C., 1970. Laboratory rearing of barnacle larvae for antifouling research. Helgoländer wiss. Meeresunters. 20, 393-405.

Torres, G., Giménez, L., 2020. Temperature modulates compensatory responses to food limitation at metamorphosis in a marine invertebrate. Funct. Ecol. 34, 1564-1576.

Torres, G., Giménez, L., Pettersen, A.K., Bue, M., Burrows, M.T., Jenkins, S.R., 2016. Persistent and context-dependent effects of the larval feeding environment on post-metamorphic performance through the adult stage. Mar. Ecol. Progr. Ser. 545, 147-160.

Tremblay, R., Olivier, F., Bourget, E., Rittschof, D., 2007. Physiological condition of Balanus amphitrite cyprid larvae determines habitat selection success. Mar. Ecol. Progr. Ser. 340, 1-8.

Underwood, A. J., 1997. Experiments in Ecology: Their Logical Design and Interpretation Using Analysis of Variance. Cambridge University Press. 
517 West, T. L., Costlow, J. D., 1987. Size regulation in larvae of the crustacean Balanus eburneus 518 (Cirripedia: Thoracica). Mar. Biol. 96, 47-58.

519 Zuo, W., Moses, M. E., West, G. B., Hou, C., Brown, J. H., 2012. A general model for effects of 520 temperature on ectotherm ontogenetic growth and development. Proc. R. Soc. B. 279, 1840-1846.

521 Zuur, A., Ieno, E., Walker, N., Savaliev, A., Smith, G., 2009. Mixed Effect Models and Extensions 522 in Ecology with R. New York: Springer.

523

524

525

526

527

528

529

530

531

532

533

534

535

536

537

538

539 
541 Table 1. Summary of best models (fixed structure) explaining the effect of temperature and food 542 limitation on survival, developmental time and body size of larvae and metamorphs of barnacles 543 Semibalanus balanoides and Austrominius modestus. Response variables Abbreviations: Factors: 544 F: food; T: temperature; interactions are abbreviated as F:T. For details on model selection are 545 given in Tables S1-S2.

546

\begin{tabular}{llll}
\hline Response variable & S. balanoides & A. modestus & Suppl Tables \\
\hline Survival: Hatching to Cyprid (log) & None & F+T & S1 \\
Dev.time: Hatching to Cyprid & F:T & F:T & S1 \\
Dev.time: Hatching to Cyprid (log) & F:T & F+T & S1 \\
Settlement success: from hatching $(\log )$ & F+T & None & S2 \\
Settlement success: from cyprid $(\log )$ & F+T & F & S2 \\
Size of cyprids & F:T & F:T & S1 \\
\hline
\end{tabular}


558 Table 2 Estimated instantaneous mortality rates (average in $\mathrm{d}^{-1}$ ) of larvae from hatching to cyprid 559 and cyprid to post-settlement in response to food and temperature.

\begin{tabular}{ccccc}
\hline & \multicolumn{2}{c}{ Hatching to cyprid } & \multicolumn{2}{c}{ Cyprid to settlement } \\
\hline S. balanoides & $\mathrm{T}=9^{\circ} \mathrm{C}$ & $\mathrm{T}=15^{\circ} \mathrm{C}$ & $\mathrm{T}=9^{\circ} \mathrm{C}$ & $\mathrm{T}=15^{\circ} \mathrm{C}$ \\
Food: Low & 0.00465 & 0.01334 & 0.08574 & 0.15727 \\
Food: Mid & 0.00406 & 0.00972 & 0.03433 & 0.05136 \\
Food: High & 0.00131 & 0.00767 & 0.03175 & 0.05753 \\
A. modestus & $\mathrm{T}=15^{\circ} \mathrm{C}$ & $\mathrm{T}=18^{\circ} \mathrm{C}$ & $\mathrm{T}=15^{\circ} \mathrm{C}$ & $\mathrm{T}=18^{\circ} \mathrm{C}$ \\
Food: Low & 0.00826 & 0.00526 & 0.02832 & 0.02735 \\
Food: Mid & 0.00426 & 0.00363 & 0.03000 & 0.03981 \\
Food: High & 0.00476 & 0.00364 & 0.01712 & 0.04510 \\
\hline
\end{tabular}

560

561

562

563

564

565 
567 Figure 1. Experimental design used to evaluate the effect of temperature and food limitation on

568 larval development of barnacles S. balanoides and A. modestus. Larvae of each species were 569 reared in separate experiments differing in the temperature treatment. For each species, larvae 570 from each parent were also reared separately.

571 Figure. 2 Percentage survival to the cyprid stage for (a) S. balanoides and (b) A. modestus; and 572 percentage survival to the cyprid stage for each parent (c) S. balanoides and (d) A. modestus at 573 different food treatments and temperatures. Error bars: (a) and (b) SD based on replicate parents. 574 (c) and (d):SD. Letters "ns" indicate non-significant differences among treatments.

575 Figure. 3 Effects of food density and temperature on settlement rates on $S$. balanoides and $A$. 576 modestus. (a) and (b) show cyprid settlement as percentage of initial number of larvae; (c) and (d= 577 show it as percentage of developed cyprids. Error bars; SD. Lower case letters indicate significant 578 differences $(\mathrm{p}<0.005)$ among food treatments; ns indicates non-significant differences among 579 treatments.

580 Figure. 4 Effects of food density and temperature for Semibalanus balanoides and Austrominius 581 modestus Average duration of development to the cyprid stage for (a) S. balanoides and (b) A. 582 modestus; and average duration of development to the cyprid stage for each parent (c) $S$. 583 balanoides and (d) A. modestus at different food treatments and temperatures. Error bars: (a) and 584 (b) SD based on replicate parents. (c) and (d):SD. Different lower case letters show significant 585 differences $(p<0.05)$ between food treatments for each species.

586 Figure 5. Cyprid area for (a) S. balanoides and (b) A. modestus; and cyprid area of larvae from 587 each parent (c) S. balanoides and (d) A. modestus at different food treatments and temperatures. 588 Error bars: (a) and (b) SD based on replicate parents. (c) and (d): SD. Different lower case letters 589 show significant differences $(\mathrm{p}<0.05)$ among food treatments for each species.

590 Figure 6. Integrated responses of body size and developmental time under different temperatures $591\left(9^{\circ} \mathrm{C}, 15^{\circ} \mathrm{C}, 18^{\circ} \mathrm{C}\right)$, and food density (low, mid, high). Error bars represent SD among larvae 592 produced by different parents $(n=4)$. 
Click here to access/download;Figure;Griffithetal-Figure- $\underline{\underline{ \pm}}$ 1.pdf
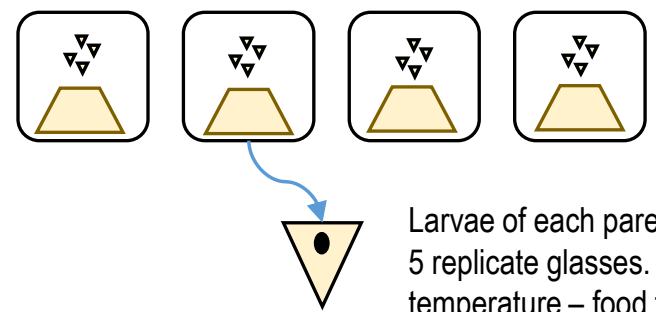

Parents release larvae in the laboratory

Larvae of each parent distributed in groups of 10 individuals in 5 replicate glasses. Replicates are assigned randomly to temperature - food treatment combinations

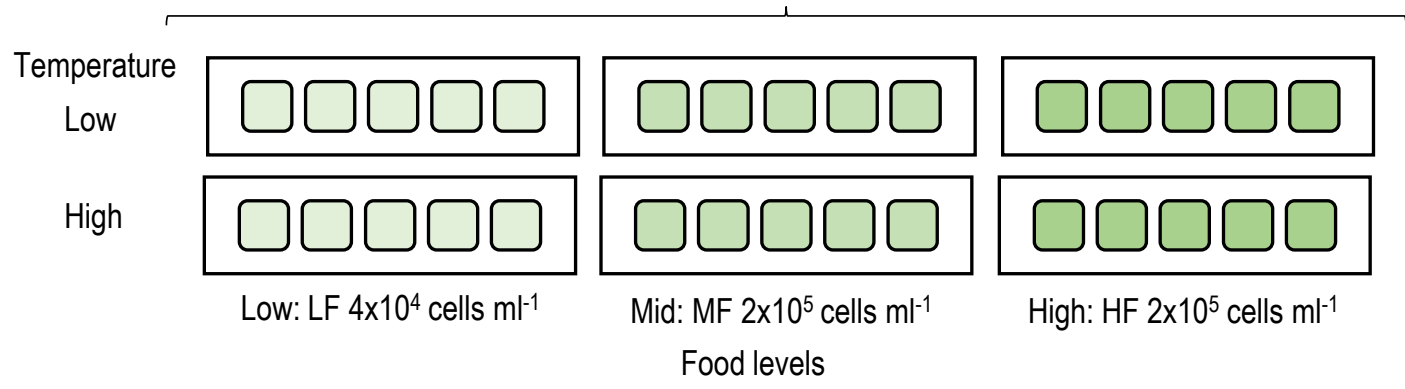

Figure 1 
S. balanoides

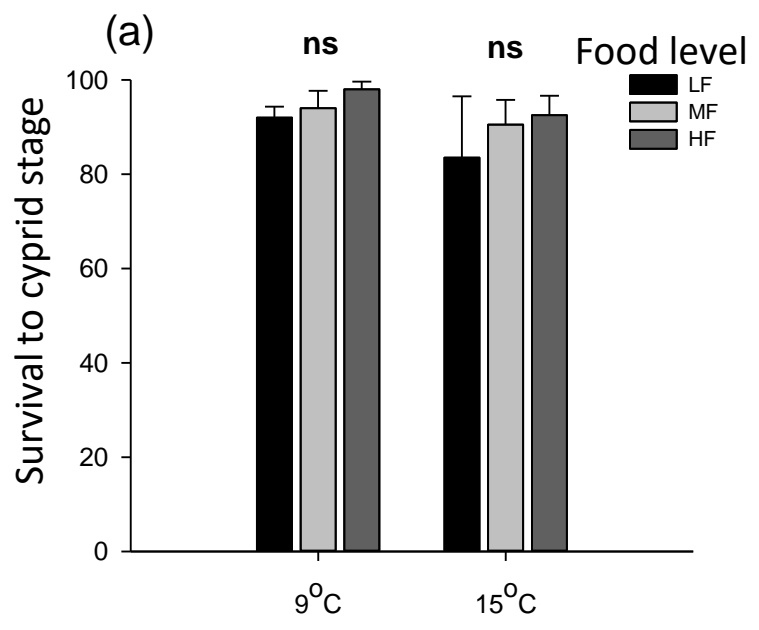

Temperature

(c)

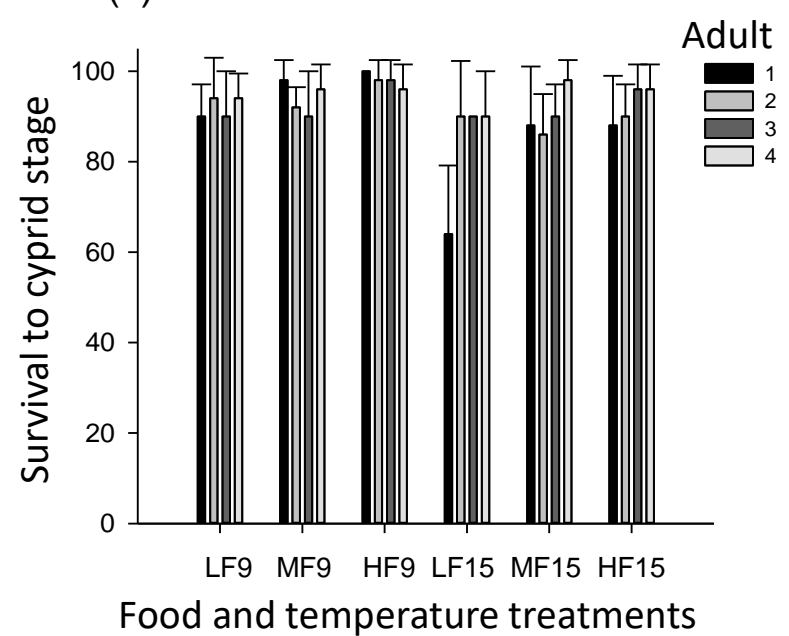

A. modestus

(b)

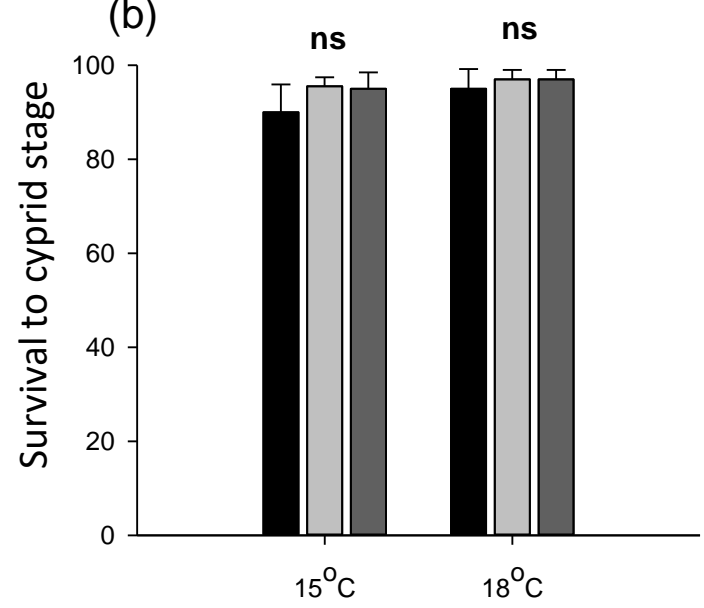

Temperature

(d)

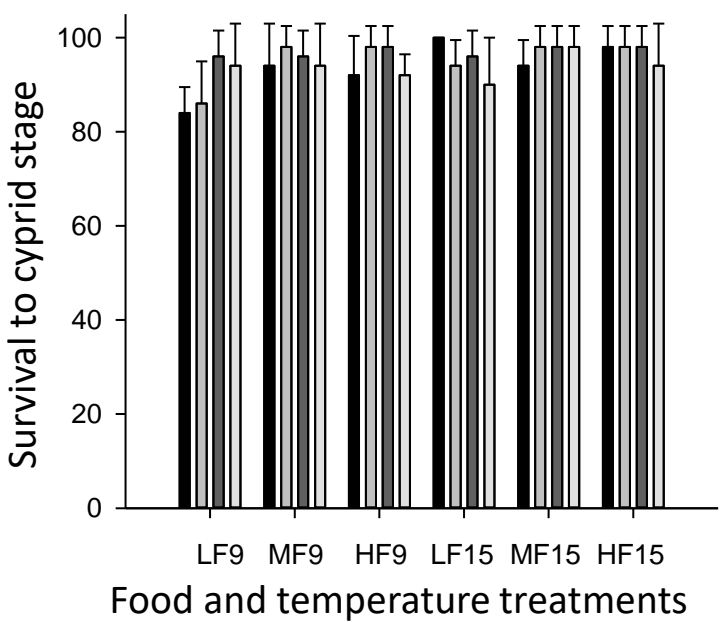

\section{Figure 2}




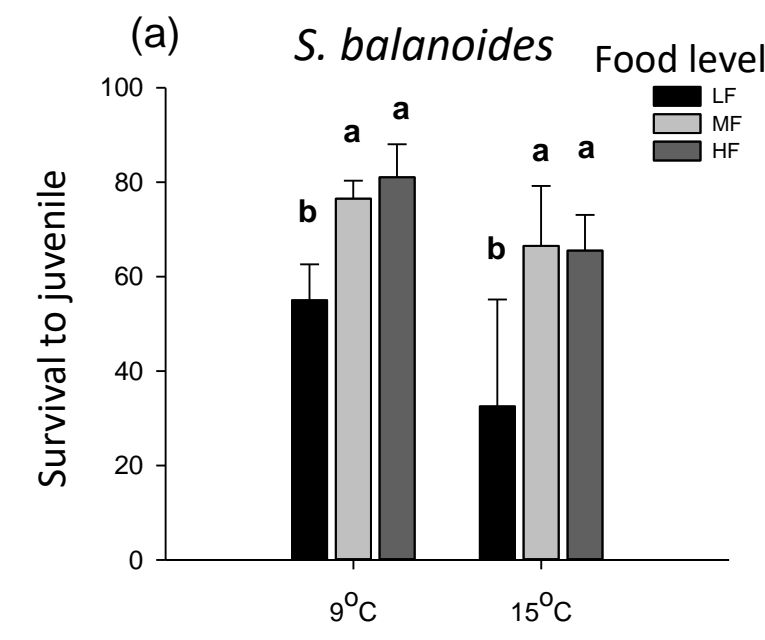

Temperature

(c)

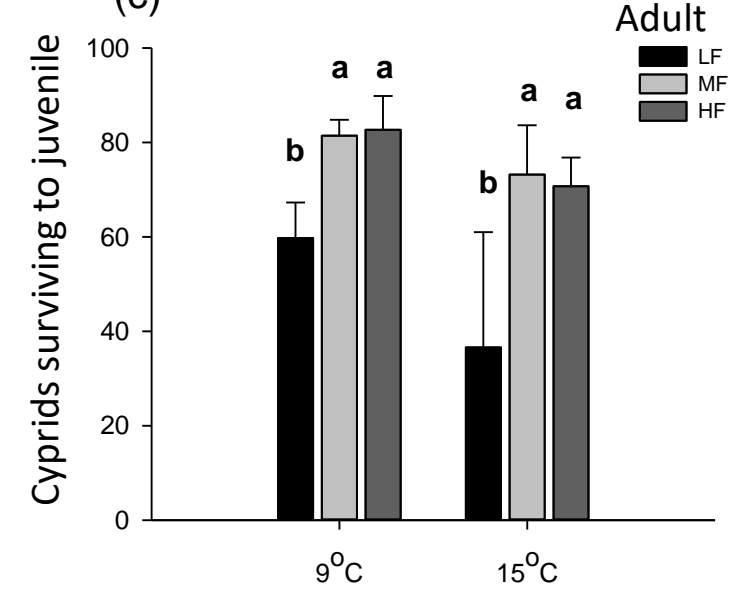

Temperature (b) A. modestus

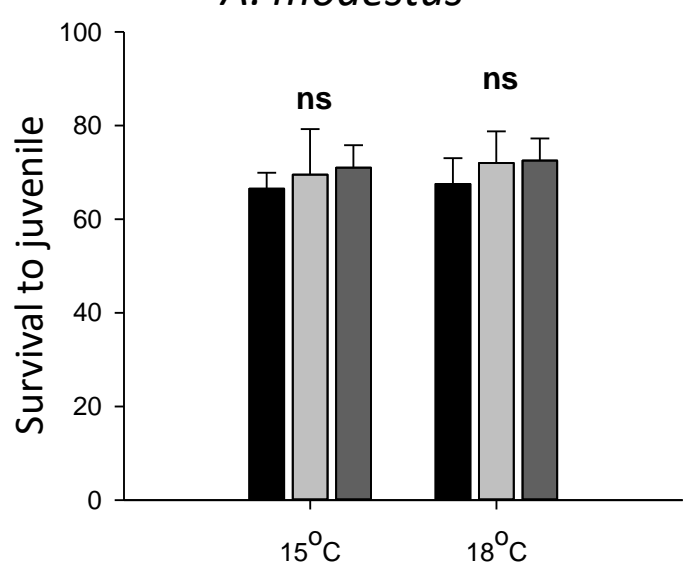

Temperature

(d)

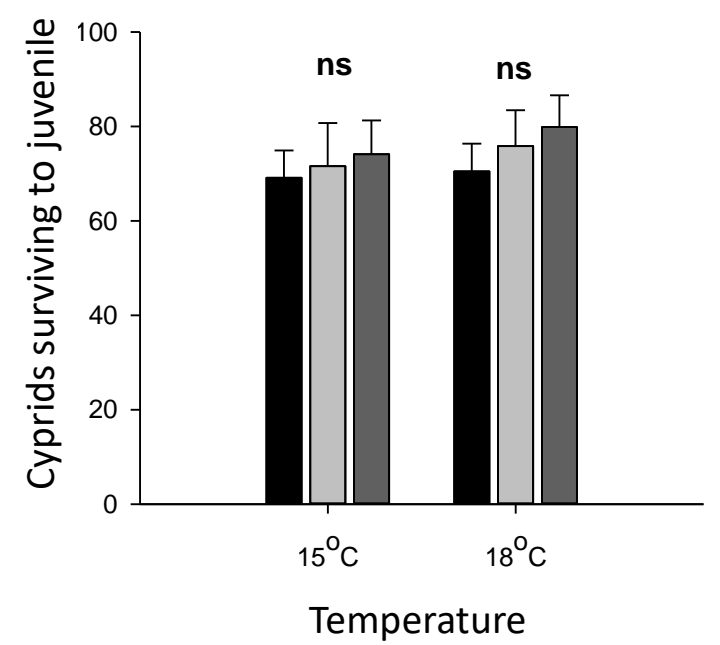

Figure 3 
(a)

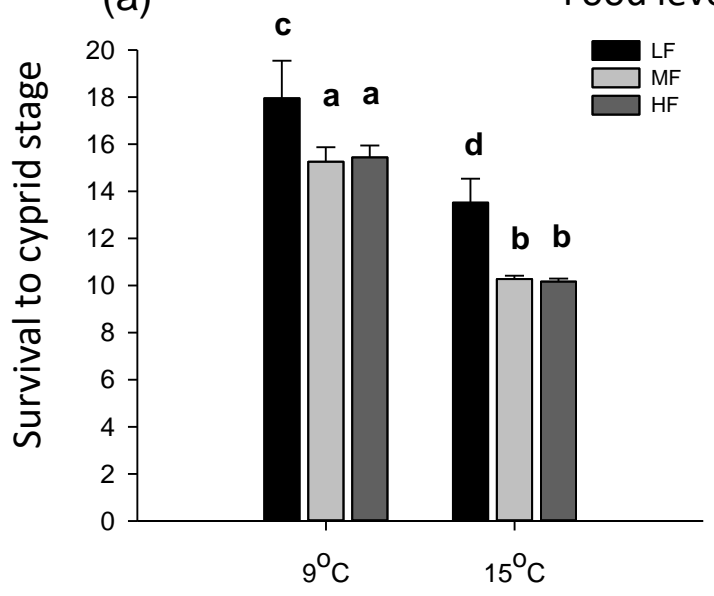

Temperature

(d)

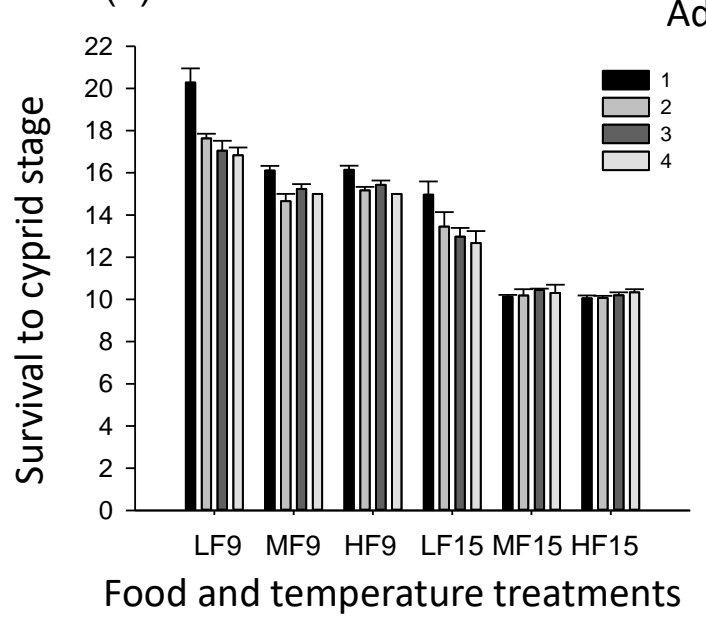

(b) A. modestus

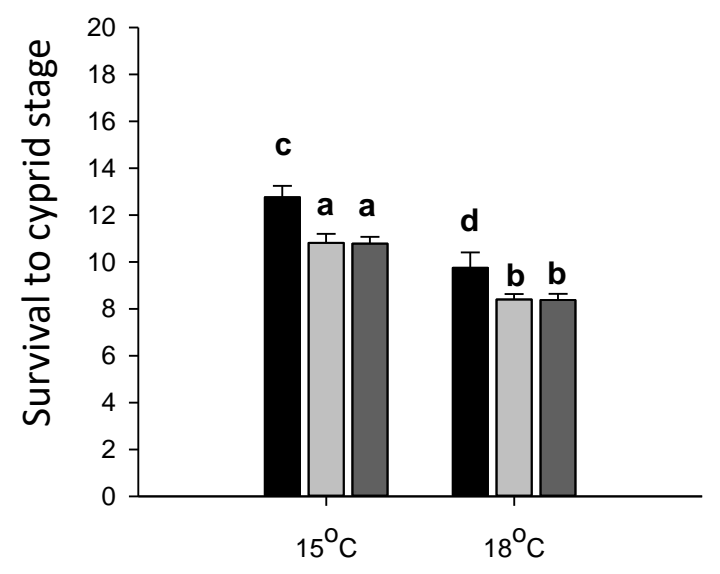

Temperature

(c)

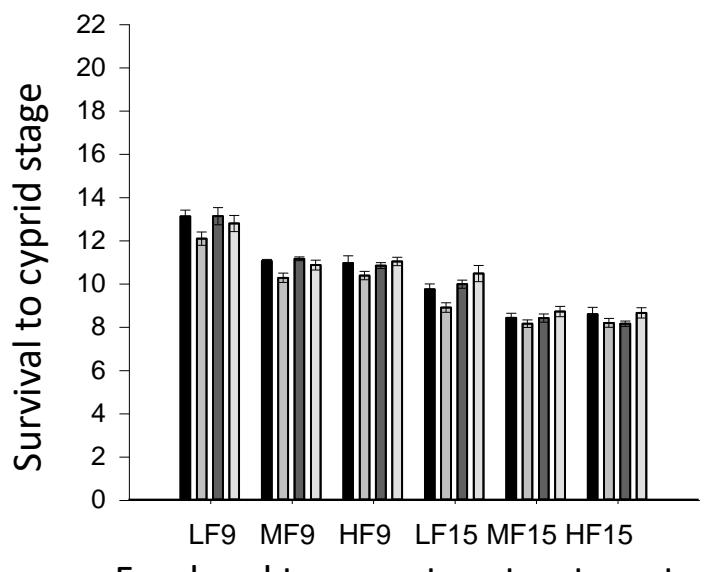

Food and temperature treatments

Figure 4 
(a) S. balanoides

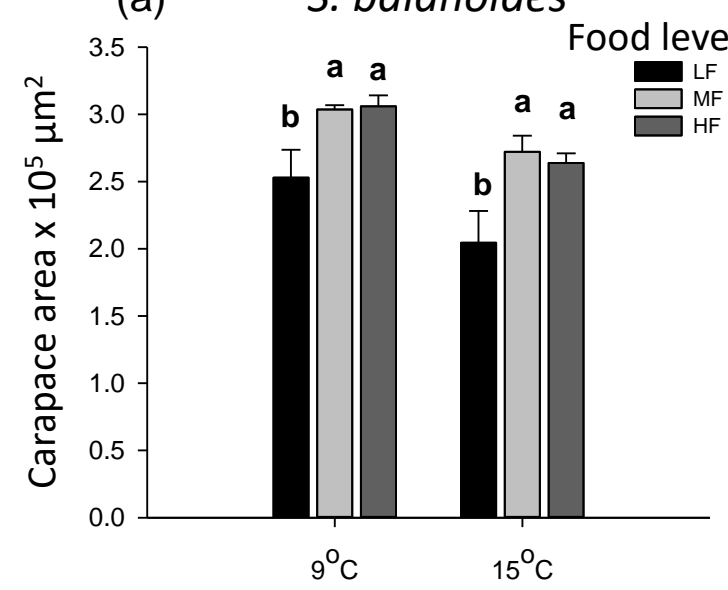

Temperature

(c)

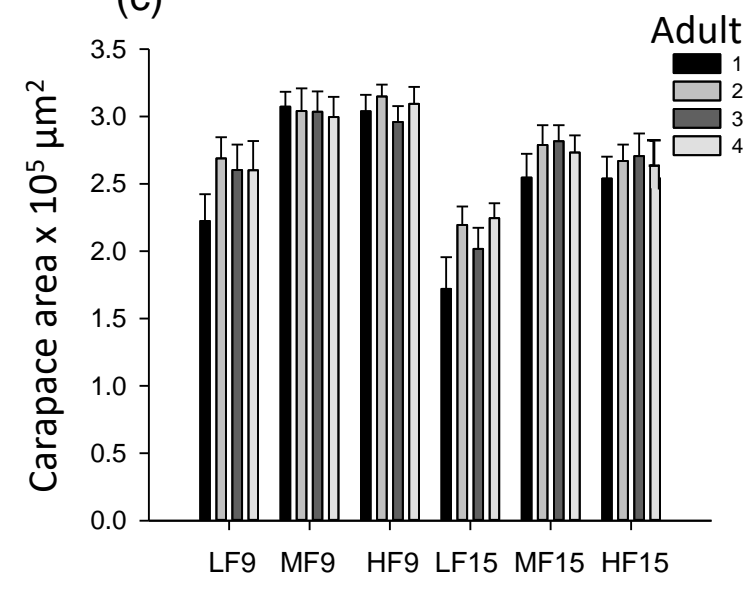

Food and temperature treatments

(b) A. modestus

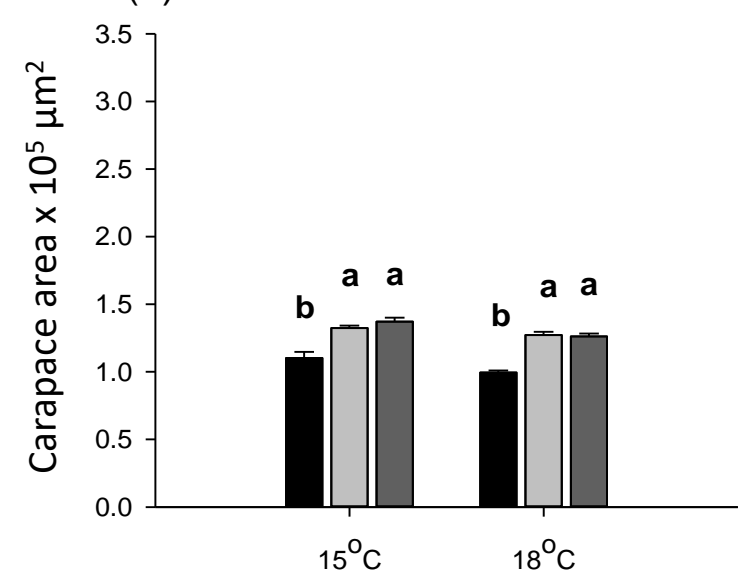

Temperature

(d)

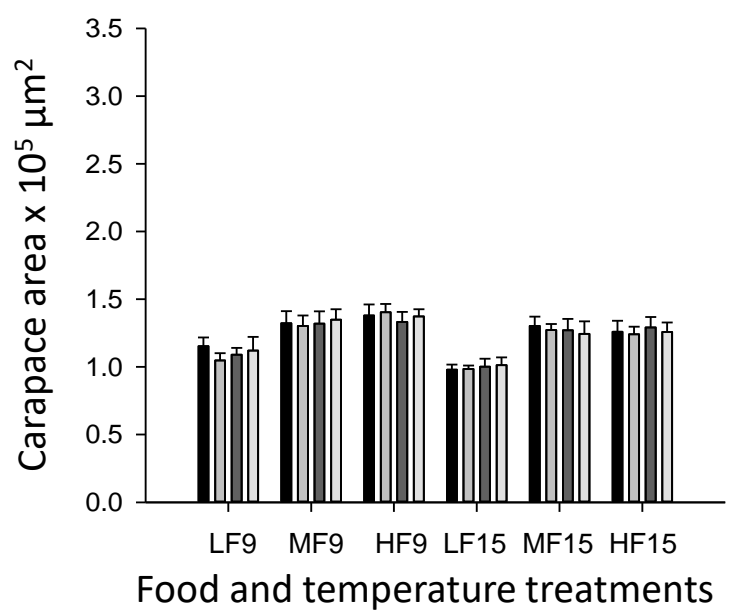

Figure 5 

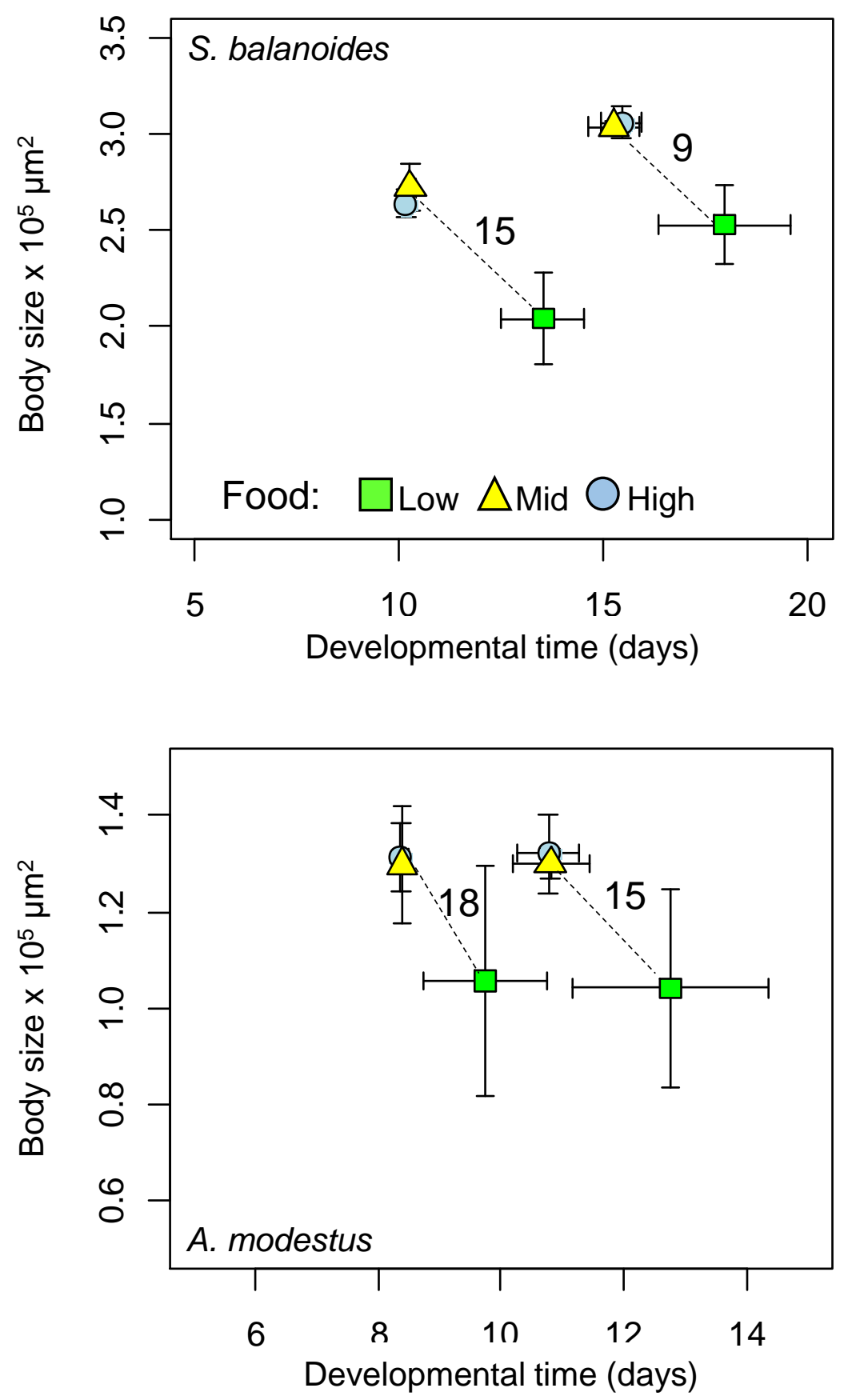
Click here to access/download e-Component GRiffithetal-R2-Suppl.docx 